\title{
Fabio y su pelota
}

\section{Génesis Feliciano, Vanessa Arroyo, Jaqueline Ordoñez Loya}

Había una vez un elefante llamado Fabio que era parte de un circo.

Fabio estaba acompañado en el circo por un tigre, un león y un oso. Los tres iban a tener una presentación muy importante en la ciudad de Nueva York y Fabio quería lucir mejor que los demás. Él quería usar todo nuevo para su presentación, menos una pelota que ya tenía.

Esa pelota era su preferida y le gustaba usarla durante sus presentaciones. La pelota era de tamaño chico y de color azul con rayas verdes. La pelota lo hacía resaltar, en comparación a los otros animales. Fabio hacía trucos únicos con ella que ni el tigre ni el león ni el oso podían hacer.

Cuando llegó el día de la presentación, Fabio decidió usar dos pelotas a la misma vez para quedar aún mejor que todos los demás. Pero una de ellas no era su pelota favorita. Durante su presentación ambas pelotas se desinflaron. Cuando las pelotas se le desinflaron, Fabio se puso muy triste porque se quedó sin su pelota favorita y quedó mal frente a todo el mundo.

\section{Moraleja}

"Quien todo lo quiere, todo lo pierde". 